\title{
Zmierzch węgla kamiennego w Polsce
}

\author{
Twilight of hard coal in Poland
}

\section{Michał Wilczyński}

Ekspert niezależny

\section{Abstract}

Poland as a country, one of the largest producers of hard and brown coal in Europe, is at the threshold of key challenges for the future of the economy. How to effectively transform the mining sector controlled by the State Treasury? Hard coal reserves suitable for economically and technically efficient production will last for less than 30 years. In the face of depletion of hard coal economic reserves, an energy strategy is urgently needed. How to manage the exploitation of brown coal, whose developed reserves will be depleted in a significant part within 8-10 years, and new ones economic reserves up to 2.6 billion $\mathrm{Mg}$, will require colossal investments and will be associated with enormous environmental, social and environmental costs?

Keywords - hard coal, resources, reserves, energy security, energy efficiency 


\section{Wprowadzenie}

W raporcie Institute for Energy Economics and Financial Analysis przygotowanego dla Norweskiego Publicznego Funduszu Emerytalnego zaleca się wycofanie aktywów ze wszystkich inwestycji w przedsiębiorstwa węglowe, gdyż: „przemysł węglowy na świecie jest w stanie strukturalnej zapaści. To zwijający się sektor z niewielkim potencjałem wzrostu" [1, s. 2].

Zmiany na globalnym rynku węgla stanowią poważne wyzwanie także dla Polski. Kraj będący w latach dziewięćdziesiątych jednym z największych producentów węgla kamiennego i brunatnego na świecie musi zmierzyć się z szeregiem trudnych pytań. W jaki sposób efektywnie zarządzać, wciąż należącym przede wszystkim do Skarbu Państwa, sektorem wydobywczym? Jak dokonać jego transformacji? Co zrobić w obliczu nieuchronnego wyczerpywania się ekonomicznych zasobów węgla kamiennego, którego zasoby nadające się do efektywnej ekonomicznie i technicznie eksploatacji wystarczą na niespełna 30 lat? Jak na konieczność importu surowca powinien przygotować się sektor energetyczny, a także organy odpowiedzialne za bezpieczeństwo energetyczne kraju? W jaki sposób zarządzać eksploatacją węgla brunatnego, którego zagospodarowane zasoby w znacznej części ulegną wyczerpaniu w ciągu 8-10 lat, a nowe, o zasobach ekonomicznych do 2,6 mld ton, wymagać będa kolosalnych inwestycji i wiązać się będa z ogromnymi kosztami środowiskowymi, społecznymi i ekonomicznymi?

Fundamentem planowania gospodarczego jest wiarygodna analiza zasobów kopalin z których gospodarka korzysta. Od ponad dwóch dekad trwa dyskusja w środowisku geologów złożowych w Polsce nad modyfikacją lub całkowitą zmianą klasyfikacji zasobów, systemu stosowanego od lat 50. zeszłego wieku, gdy kryteria ekonomiczne wydobywania kopalin nie odgrywały żadnej roli.

Ten problem zauważają autorzy Programu dla sektora górnictwa wegla kamiennego w Polsce: „Stosowana jednak w praktyce klasyfikacja zasobów węgla kamiennego okazuje się niewystarczająca. Obecne trendy i tendencje rynkowe zmierzają w kierunku systemów klasyfikacji zasobów złóż, uwzględniających w większym stopniu ich biznesowy charakter, pozwalający na budowanie planów rozwoju kopalń w oparciu o wartość gospodarczą i ekonomiczną oraz wpływając tym samym na możliwości w zakresie pozyskiwania przez przedsiębiorców zróżnicowanych źródeł finansowania dla przyszłych inwestycji. 
Systemy te (m.in. NI43101, JORC) stanowią obecnie wymóg inwestorski na wielu giełdach światowych" [2, s. 5].

\section{Krytycznie o zasobach i perspektywach wydobycia węgla w Polsce}

Operowanie wielkościami zasobów geologicznych, słabo rozpoznanych, a ujawniającymi wielkie liczby, nosi cechy propagandy sukcesu i prowadzi do skrajnie mylących wniosków w rodzaju: możliwości wydobywania węgla kamiennego przez 100 czy 200 lat. Dla oceny dostępności węgla dla energetyki kluczowe są wielkości zasobów operatywnych a nie geologicznych bilansowych. Zasoby operatywne to pomniejszone o straty zasoby przemysłowe, możliwe do wydobycia po uzasadnionych ekonomicznie kosztach.

Zgodnie z Bilansem zasobów złóż kopalin w Polsce, który jest sporządzany corocznie w myśl ustawy Prawo geologiczne i górnicze [3] i zatwierdzany przez Głównego Geologa Kraju, autor obliczył, iż na koniec roku 2016 zasobów przemysłowych we wszystkich złożach węgla kamiennego w Polsce było 2,982 mld ton, rok wcześniej - 3,573 mld ton, zatem w ciagu roku ubyło 0,591 mld ton zasobów przemysłowych, a wydobyto 66,5 mln ton. W latach 1990-2016 wydobyto łącznie 2,7 mld ton węgla kamiennego, a ubytek zasobów przemysłowych wyniósł 11,95 mld ton. Także w latach 20122016 wydobyto 337,27 mln ton, a zmniejszenie zasobów przemysłowych wyniosło 1195,3 mln ton [4]. W Programie dla sektora górnictwa wegla kamiennego w Polsce przyjętym przez Radę Ministrów 23 stycznia 2018 roku [2, s. 6] w tab.1a przyjęto, że poziom teoretycznych strat w zasobach przemysłowych w latach 2010-2015 wynosił od 29,8 \%, w roku 2010 do 7,5 \% w roku 2015. Przygotowując Projekt Zagospodarowania Złoża przyjmuje się minimum 30\%, a w praktyce jest to $40-56 \%$.

Zaniżając poziom strat w złożu dokonuje się swoistej wirtualnej bilansowości złoża, gdy w rzeczywistości wystarczalność zasobów jest znacznie mniejsza. Tym, między innymi, można by tłumaczyć problem dużych ubytków w zasobach przemysłowych wykazywanych w Bilansie Zasobów Złóż Kopalin w Polsce, o czym pisano powyżej.

Krytycznym elementem wyznaczającym granice geologiczne złoża kopaliny staje się poprawne przyjęcie granicznych wartości parametrów definiujących złoże (zgodnie z [5]), według których zasoby kopalin moga być uznane za możliwe do zagospodarowania i wykorzystania w przyszłości. Wartości parametrów powinny ulegać zmianom nie tylko z powodów górniczych czy ekonomicznych, ale także z powodu rosnących 
wymagań ochrony środowiska, skomplikowanej budowy geologicznej czy wreszcie braku akceptacji społeczności lokalnej. Zasoby kopaliny w bilansie zasobów moga zatem rosnąć lub maleć, mimo iż fizycznie w złożu nie będą się dokonywać żadne zmiany. Efekt ten będzie się pojawiać, gdy administracyjnie zmieniane są graniczne wartości ${ }^{1}$.

Jeśli poszczególne części złoża spełniają ustalone przez Ministra Środowiska graniczne wartości parametrów definiujących złoże, zasoby geologiczne złoża są określane jako bilansowe. W przypadku węgla kamiennego obecnie obowiązują trzy kryteria:

- maksymalna głębokość dokumentowania $1250 \mathrm{~m}$;

- minimalna miąższość węgla kamiennego w pokładzie wraz z przerostami o grubości do 0,3-0,6 m;

- minimalna średnia ważona wartość opałowa węgla kamiennego w pokładzie wraz z przerostami - $15 \mathrm{MJ} / \mathrm{kg}$.

Ten „mechanistyczny” system kwalifikacji zasobów funkcjonuje od wczesnych latach 50. XX wieku, został wprowadzony w innej rzeczywistości ustrojowej, w której kryteria wartości ekonomicznej złoża nie odgrywały istotnej roli w podejmowaniu decyzji o jego eksploatacji.

W standardach międzynarodowych, takich jak ramowa klasyfikacja ONZ zasobów surowców mineralnych i paliw stałych (UNFC) czy JORC Code, ocenę wartości i znaczenia zasobów przeprowadza się według trzech kryteriów - układ trójwymiarowy (rysunek 1):

- atrakcyjności technicznej i ekonomicznej złoża,

- dokładności oceny warunków technicznych i ekonomicznych zagospodarowania złoża,

- stopnia geologicznego poznania złoża.

\footnotetext{
${ }^{1}$ Przykładem „księgowego” przyrostu zasobów wskutek zmiany kryteriów bilansowości podaje wykonane w roku 2011 na zlecenie Ministra Środowiska opracowanie Weryfikacja zasobów wegla kamiennego w żożach zlikewidowanych kopaln wraz z.pręeliczeniem ich zasobów w oparciu o obowiazujace graniczne wartosici parametrón definiujacych żłoże. Bez jakichkolwiek dodatkowych robót geologicznych wykonano dodatki do dokumentacji geologicznych dla 38 złóż węgla kamiennego. Dzięki przesunięciu granicy dokumentowania z 1000 m do 1250 m głębokości poniżej terenu, ,przyrost” geologicznych zasobów bilansowych wyniósł 3396,98 mln ton, w tym: w Zagłębiu Górnośląskim - 2947,84 mln ton, a w Zagłębiu Lubelskim - 359,72 mln ton. Według obowiązujących w roku 2011 kryteriów do zasobów bilansowych zaliczono zasoby węgla zakwalifikowane wcześniej, podczas restrukturyzacji przemysłu węglowego, do zasobów pozabilansowych.
} 
Rysunek 1. Międzynarodowa klasyfikacja zasobów (UNFC), model uproszczony

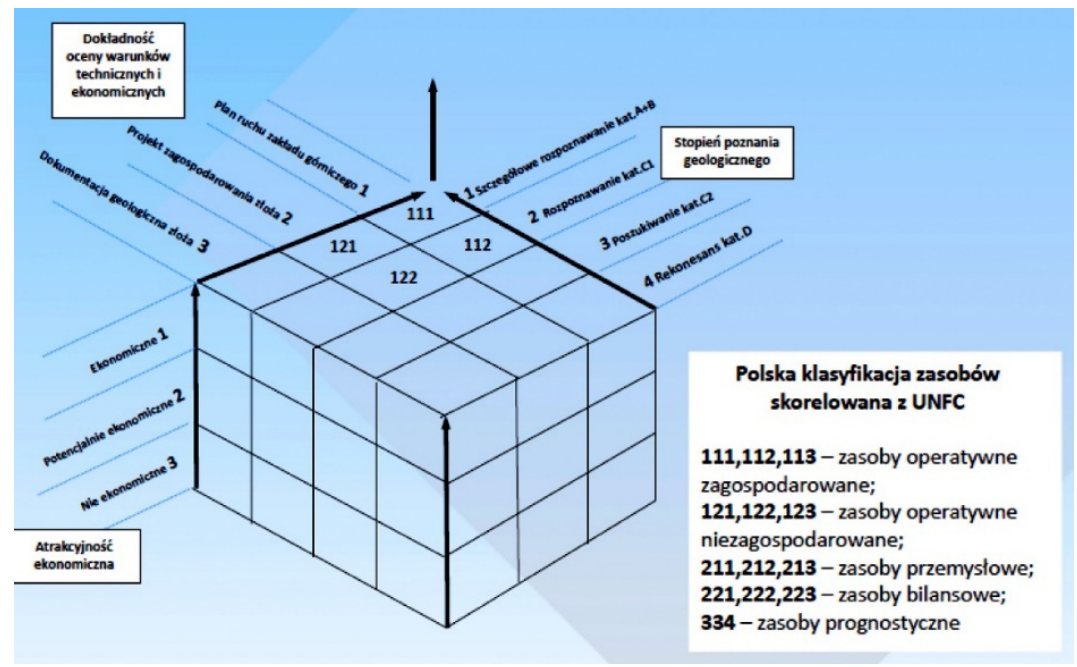

Źródło: opracowanie własne na podstawie [6], [7].

Autor podjął próbę oceny zasobów węgla kamiennego w Polsce (rysunek 2) uwzględniając dokładność rozpoznania i przyporządkowując terminologię kodeksu JORC.

Rysunek 2. Struktura i stan rozpoznania zasobów węgla kamiennego w Polsce

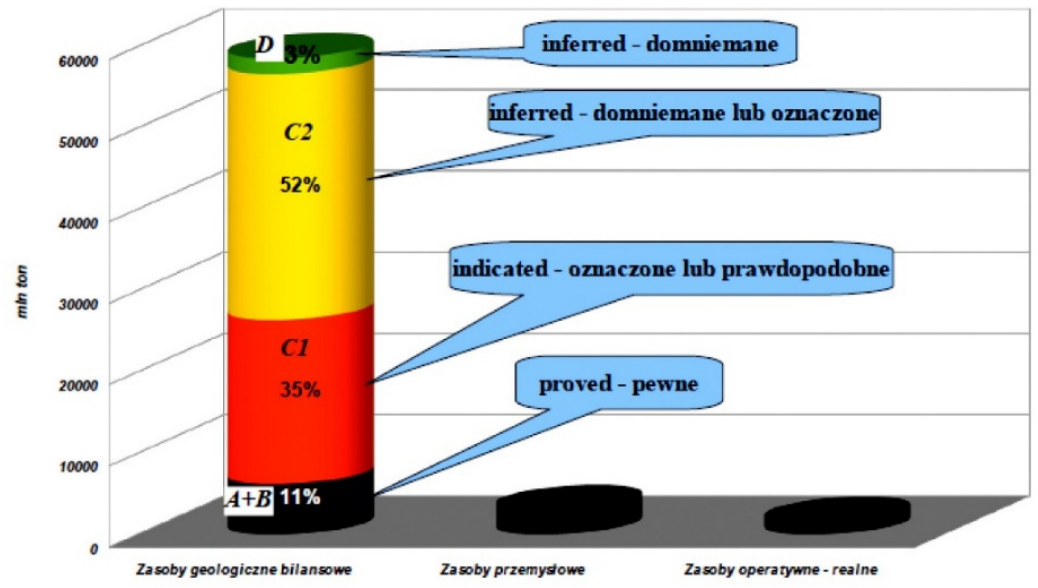

Źródło: Opracowanie autora na podstawie [4]. 
Z analizy tej wynika, że zasobów pewnych i potwierdzonych (proven reserves - kategoria rozpoznania A+B) mamy zaledwie 11\% (6,197 mld ton), z czego zasobów zagospodarowanych, przemysłowych jest 2,982 mld ton. Uwzględniając straty na realnym, niskim poziomie $40 \%$, do wydobycia pozostaje $1,789 \mathrm{mld}$ ton.

W świetle powyższych danych trudno znaleźć podstawy optymizmu co do „ogromu zasobów", przedstawiane w różnych oficjalnych dokumentach. Uwzględniając tempo zmniejszania zasobów przemysłowych z lat 2012-2016 (mniejsze niż w latach 1990-2011) i wydobycie na poziomie $70 \mathrm{mln}$ ton/rok, to wystarczalność zasobów zagospodarowanych nie przekroczy 25 lat.

Nadzieje na możliwość wydobywania węgla z głębokości 1000-1250 m mogą okazać się wysoce płonne, gdyż wiążą się z wieloma problemami techniczno-geologicznymi, a zatem wysokimi kosztami wydobycia. Przy eksploatacji głęboko położonych pokładów potęgują się zagrożenia naturalne (wysoka temperatura, wysoka zawartość metanu, skłonność do tąpnięć i wstrząsów górniczych), a skuteczne przeciwdziałanie tym zagrożeniom znacznie zwiększa koszty, obniżając bieżącą rentowność wydobycia. Program dla sektora górnictwa wegla kamiennego w Polsce trafnie definiuje problem trendów cenowych węgla na rynku międzynarodowym: „Sytuacja rynkowa na świecie wskazuje również, że polskie górnictwo węgla kamiennego funkcjonuje (i w najbliższych latach może funkcjonować dalej) w warunkach niskich cen węgla, co decydować będzie o kosztowej konkurencyjności producentów. Mimo, że w ciagu ostatnich miesięcy 2016 r. zarówno w przypadku cen węgla energetycznego, jak też koksowego obserwowany był trend wzrostowy, według obecnych ocen jest mało prawdopodobne, by ta tendencja utrzymała się w kolejnych latach" [2, s. 4].

Koszty wydobycia w Polsce węgla kamiennego, a ceny węgla na rynku europejskim

Kluczowym zagadnieniem dla przyszłości sektora węgla kamiennego w Polsce jest poziom kosztów wydobycia. Jak to ujęto w Programie dla sektora górnictwa wegla kamiennego w Polsce: „Po okresie osiagania dodatnich wyników finansowych netto do 2012 r. (7,9 mln zł w 2009 r.; 3013,9 mln zł w 2011 r.) od 2013 r. sektor osiaga ujemne wyniki finansowe do 2,2 mld zł w 2015 r. Po uwzględnieniu odpisów z tytułu utraty wartości środków trwałych, strata osiągnęła poziom 4,5 mld zł, przy stracie ze sprzedaży węgla na poziomie 2,0 mld zł” [2, s. 38]. 
Jednakże stwierdzenie to pomija pomoc publiczną udzielaną od roku 1990 aż do tej chwili. Według szacunków ekspertów WISE Europa, łączna wielkość pomocy publicznej dla górnictwa węgla kamiennego i brunatnego w latach 1990-2016 wyniosła 167,6 mld zł [8,9]. Korzystając z tych danych autor szacuje, iż na górnictwo węgla kamiennego przypadło co najmniej 135 mld pomocy publicznej. Wobec wydobycia w tym czasie 2,7 mld ton węgla kamiennego do każdej tony wydobytego węgla obywatele naszego kraju dopłacili średnio $50 \mathrm{zł}$.

Na rynkach międzynarodowych obowiązują standardy jakości węgla ${ }^{2}$ i dla przykładu cena węgla energetycznego na rynku ARA (Amsterdam, Rotterdam, Antwerpia) dotyczy węgla o kaloryczności $25,14 \mathrm{GJ} /$ tona, podczas gdy polski węgiel energetyczny w obrocie krajowym to średnio ok. $22 \mathrm{GJ} /$ tona. Przykład korelacji cen na rynku europejskim przedstawia rysunek 3 .

Jedynie w roku 2011 tona węgla energetycznego o standardowej kaloryczności 25,14 GJ była droższa o 82 zł na rynku ARA od polskiego węgla loco kopalnia o przeliczonej wartości kalorycznej na standard ARA. Od roku 2012 do 2016 włącznie polski węgiel jest droższy o 24,5 zł, loco kopalnia od węgla CIF ARA. Krzywa prezentująca koszty wydobycia 1 GJ energii (dla węgla jakości ARA, tj. 25,14 GJ/tona) ujawnia nadwyżkę kosztów wydobycia nad ceną loco kopalnia, jak i CIF ARA. W roku 2016 koszt wydobycia 1 GJ energii był wyższy od ceny 1 GJ na rynku ARA o 4,9 zł, i 2,4 zł wyższy od ceny loco kopalnia.

Analizując dostępne dane z lat 2007-2016 [10] oraz dodając do nich te niepełne i trudno dostępne o funkcjonowaniu sektora górnictwa węgla kamiennego w Polsce, można ujrzeć problem strukturalny tej branży, polegający na szybko rosnących kosztach wydobycia, zwłaszcza do roku 2012, przy spadajacym wydobyciu. Najszybciej spadało wydobycie węgla energetycznego, z 73,8 mln ton w roku 2007 do 53 mln ton w roku 2017.

W tym okresie wydobycie węgla koksującego utrzymało się na dość stałym poziomie 12-13 mln ton rocznie. Koszty wydobycia rosły z roku na rok i dla przykładu w roku 2012 wzrosły o 10,2 \% (o 2197,3 mln zł), przy wzroście wydobycia o 3,7\%. Na rynku NW Europy (ARA) do roku 2003 ceny węgla energetycznego nie przekraczały 40 USD/tonę, ale już w roku 2004 zaczęły szybko rosnać od poziomu 43,6 USD/tona,

\footnotetext{
2 Porozumienie Standard Coal Trading Agreement (SCoTA) obejmuje wszystkie rynki handlu węglem i 2400 licencjonowanych firm.
} 
poprzez 72,08 USD/tona w 2005, by w roku 2008 osiagnąć maksimum ceny - 147,67 $\mathrm{USD} /$ tona [11].

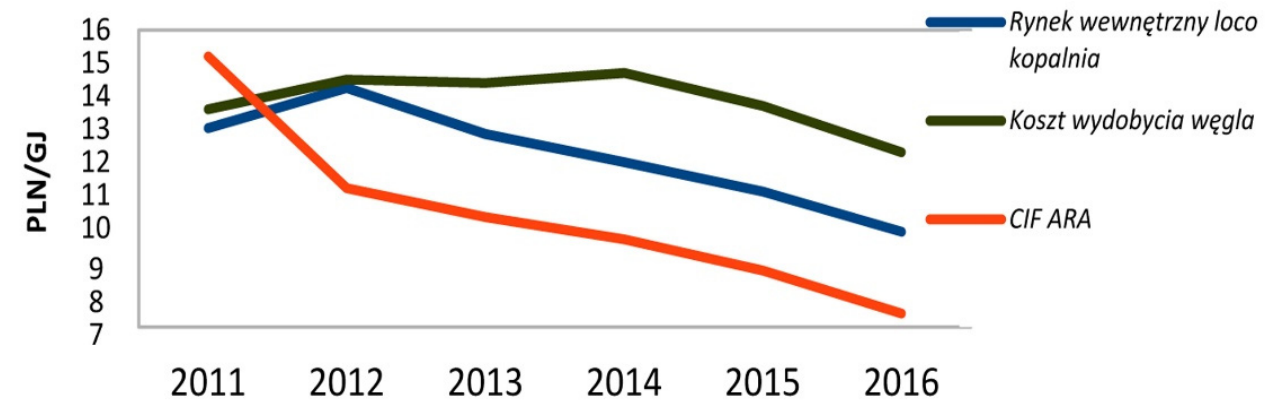

Rysunek 3. Relacje cen węgla energetycznego pozyskanego w kraju do węgla na rynku Europy NW (ARA)

Źródło: opracowanie autora, z wykorzystaniem danych ARP dla cen rynku wewnętrznego, dane dla ARA [15], kursy średnie PLN/USD za NBP. Dla obu rynków węgla przeliczono wartość kaloryczną węgla wg standardu ARA Q=25,14 GJ/Tona. Koszt wydobycia wg danych Ministerstwa Cospodarki przeliczone na standard węgla ARA = 25,14 G).

Po tym okresie boomu cenowego, wywołanego przez gwałtownie rosnący popyt gospodarki Chin na węgiel, ceny równie gwałtownie zaczęły spadać. Równocześnie okres boomu węglowego spowodował równie intensywny wzrost wydobycia węgla w Chinach, Australii, Indonezji i Rosji, a także wzrost eksportu węgla z USA (spowodowany rosnącym wydobyciem gazu łupkowego w tym kraju i spadkiem tamtejszego zapotrzebowania na ten surowiec energetyczny).

Procesy te zmieniły trwale światowy rynek węgla i obecnie przy wolniej rosnaccym zużyciu w Chinach i w krajach OECD, na rynku światowym utrzymuje się nadpodaż węgla. Jednocześnie polskie spółki skarbu państwa konsumowały przychody zwiększając koszty stałe, bez poprawy bardzo niskiej wydajności jednostkowej wydobycia (550$650 \mathrm{t} / \mathrm{rok} / \mathrm{os})$, zaniedbujacc inwestycje odtworzeniowe.

\section{Znaczenie węgla kamiennego}

w zapewnieniu bezpieczeństwa energetycznego Polski

Według Międzynarodowej Agencji Energii, bezpieczeństwo energetyczne to nieprzerwana fizyczna dostępność dostaw, po przystępnej cenie, wykorzystywana w zgodzie ze 
środowiskiem [12]. Bardzo podobna jest definicja zawarta w polskiej ustawie Prawo energetyczne: „Bezpieczeństwo energetyczne jest to stan gospodarki umożliwiający pokrycie bieżącego i perspektywicznego zapotrzebowania odbiorców na paliwa i energię w sposób technicznie i ekonomicznie uzasadniony przy zachowaniu wymagań ochrony środowiska" [13, art. 3, pkt. 16]. Nie ma tu zobowiązania do zaopatrywania w paliwa i energię ze źródeł krajowych bez względu na koszty i skutki środowiskowe.

Niestety, w wielu dokumentach rządowych wskaźnik uzależnienia od importu energii pierwotnej został podniesiony do rangi głównej wytycznej polityki energetycznej: „Dostęp do własnych zasobów węgla daje bezpieczeństwo energetyczne oraz pozwala zmniejszyć wystąpienie negatywnych skutków niepewności gospodarczej na rynkach. W większości państw UE obserwuje się wzrost wskaźnika zależności od importu nośników energii. W Polsce, dzięki posiadaniu i eksploatacji złóż węgla, poziom bezpieczeństwa energetycznego, oceniany przez pryzmat wskaźnika uzależnienia od importu, oscyluje obecnie na poziomie $\mathbf{2 0} \%$, wobec $53 \%$ dla wszystkich krajów UE” [2, s. 7].

Uwaga pierwsza do powyższego cytatu: według danych GUS wskaźnik uzależnienia w roku 2015 wyniósł 29,3\%, a nie 20\% [14, s. 3].

Uwaga druga: w kwestii wykorzystania węgla w Polsce od wielu dekad pomija się tę część definicji bezpieczeństwa, która mówi o pokryciu zapotrzebowania na paliwa i energię w sposób technicznie i ekonomicznie uzasadniony przy zachowaniu wymagań ochrony środowiska - z naciskiem na „zachowanie wymagań ochrony środowiska”. Co do części definicji bezpieczeństwa energetycznego odnoszącej się do „ekonomicznie uzasadniony”, to wcześniej wskazano, iż od roku 1990 gospodarka narodowa obciążona jest ogromną pomoca publiczną dla sektora górnictwa węglowego (średnio 8,5 mld zł rocznie [13, s. 29]), a udział tego sektora w tworzeniu dochodu narodowego jest minimalny. W latach 2006-2013 wkład górnictwa węglowego w realny wzrost PKB wynosił średnio -0,02\% [20, s. 10]. W Programie dla sektora górnictwa wegla kamiennego w Polsce podano, że: „Średni udział płatności publicznoprawnych zrealizowanych w latach 2007-2015 przez górnictwo węgla kamiennego w dochodach ogółem sektora finansów publicznych w tych latach wyniósł 1,19\%” [2, s. 18]. Przy czym w roku 2016 udział ten wyniósł zaledwie 0,77\% dochodów sektora finansów publicznych [ibidem, s. 19, tab. 2.1.3].

Raport Naczelnej Izby Kontroli z roku 2017 wskazuje, że: „Skala zrealizowanych płatności publicznoprawnych przedsiębiorców górniczych w latach 2007-2015 była 
porównywalna z kwotą wsparcia, jakie górnictwu udzielił Skarb Państwa, co można zobrazować stwierdzeniem, że wypracowane przez sektor środki w całości do niego powróciły" [16, s. 66]. Dodajmy, że skumulowana pomoc publiczna w tym czasie wyniosła $65,7 \mathrm{mld}$ zł, a płatności publicznoprawne $64,5 \mathrm{mld}$ zł [16, s. 66].

Także w wymiarze regionalnym, województwa śląskiego, przedsiębiorstwa z działu "górnictwo i wydobywanie" w roku 2015 odnotowały ujemny wynik finansowy netto 4204,7 mln zł, podczas gdy przedsiębiorstwa przetwórstwa przemysłowego osiagnnęły 7572,5 mln zł zysku netto, a dział „handel: naprawa pojazdów samochodowych” 1394,5 mln zł. Ogółem wynik finansowy netto przedsiębiorstw województwa śląskiego w roku 2015 wyniósł 1274,9 $\mathrm{mln}$ zł [17, s. 381-382]. W tym też roku w typowo rolniczej Wielkopolsce dodatni wynik finansowy netto przedsiębiorstw wyniósł $13936,5 \mathrm{mln}$ zł. Także i tam górnictwo i wydobywanie (węgiel brunatny) wytworzyło zaledwie $+18,7$ mln zł zysku netto, co stanowiło 0,13\% wyniku finansowego netto przedsiębiorstw całego regionu [18, s. 320-321].

Analizując strukturę odejść z górnictwa w 2016 roku [14, dane za rok 2016] niepokoić powinien fakt, że w $90 \%$ byli to pracownicy produkcji (dołowi i zakładów przeróbki), a wśród nich ponad 13\% to pracownicy dozoru technicznego. Przypomnieć trzeba, że do pracy w górnictwie pod ziemią prawnie wymagane są szczególne kwalifikacje i uprawnienia. Wśród dozoru technicznego dominują osoby z wyższym wykształceniem, a górnicy to najczęściej specjaliści, bardzo poszukiwani przez inne przedsiębiorstwa (elektrycy, mechanicy, spawacze itp.). Zakłady górnicze zaczynają odczuwać brak wysoko wykwalifikowanego personelu dołowego. W tej sytuacji do pracy na dole zatrudnianych jest 3000-4000 emerytów górniczych.

Dane prezentowane w Programie dla sektora górnictwa wegla kamiennego w Polsce dokumentują fakt konsekwentnie malejącego znaczenia węgla w bilansie energetycznym. W bilansie zużycia energii pierwotnej znakomicie widoczna jest spadkowa tendencja węgla kamiennego od roku 2007 i szybko rosnące zużycie ropy naftowej, dodajmy pochodzącej w 95,3\% z importu. Weegiel brunatny jeszcze utrzymuje swój udział w bilansie zużycia energii pierwotnej w granicach 11-12\%, lecz około roku 2030 z czynnych 8 kopalni odkrywkowych pozostaną tylko dwie: Szczerców i Turów [2, tab. 2.1.2a].

W rządowym Programie dla sektora górnictwa wegla kamiennego w Polsce znajdujemy taka oto tezę: „Zużycie energii elektrycznej związane jest z dynamiką produktu krajowego brutto PKB” [2, s. 14]. Jednak uważna analiza rys.2.1.2d na tej samej stronie zaprzecza 
tej tezie. Dynamika zmian PKB i zużycia energii elektrycznej w latach 2007-2015 pokazują, że w roku 2015 PKB wzrósł o 3,9\%, a zużycie energii elektrycznej tylko o 2\%, w roku 2014 PKB podniósł się o 3,3\%, a zużycie energii elektrycznej jedynie o 0,7\%, w roku 2013 PKB wzrósł o 1,7\%, a zużycie energii elektrycznej o 0,5\% i wreszcie w roku 2012 PKB zwiększył się o 1,8\%, a zużycie energii elektrycznej wzrosło o $0,6 \%$.

W tym miejscu należy przypomnieć, że w pierwszych dwóch dekadach niepodległej Polski PKB został podwojony przy zerowym wzroście zużycia energii pierwotnej. Wielkim sukcesem gospodarki narodowej było radykalne zmniejszanie energochłonności PKB. Autor policzył, korzystając z danych Eurostatu [19], iż energochłonność polskiego produktu krajowego brutto w roku 2000 wynosiła 357,14 kg eq. ropy/1000 euro PKB, a w roku 2016 było to 232,56 kg eq. ropy/1000 euro PKB. A mimo to polska gospodarka nadal ma ogromnie dużo do zrobienia w zakresie ograniczania energochłonności, na przykład w porównaniu do energochłonności PKB w RFN, która w roku 2016 wynosiła 111,11kg eq. ropy/1000 euro PKB [19]. Truizmem jest stwierdzenie, że inwestycje w poszanowanie energii sa znacznie mniej kosztowne niż nowe moce wytwórcze.

\section{Podsumowanie}

W drugiej dekadzie XXI wieku wiele faktów wskazuje na zmierzch epoki węgla [20]. Zasobność złóż węgla w różnych częściach świata nie może być argumentem za kontynuowaniem „epoki węglowej”. Przecież epoka kamienia (paleolit i neolit) nie skończyła się dlatego, że zabrakło kamienia. Człowiek doskonalił technologie i narzędzia, cywilizacyjnie wkraczając w kolejne epoki: brązu, żelaza... Współcześnie, w ciągu życia jednego pokolenia, dokonał się gigantyczny skok technologiczny i cywilizacyjny; od suwaka logarytmicznego do lotów kosmicznych, superkomputerów, nowych, wcześniej nie znanych materiałów. Także w świadomości ludzi dokonują się zmiany w myśleniu o otaczajacym nas środowisku i naszym w nim miejscu. Coraz częściej dostrzegamy relacje naszego zdrowia i poczucia komfortu ze stanem środowiska. Coraz więcej ludzi nie godzi się na dewastację zasobów środowiska, z którym współistniejemy. Grupy ludzi i naukowcy potrafią wyjść poza myślenie „tu i teraz” i ostrzegać przed tym, co może nas 
czekać za 20-30 lat. Przykładem tego jest działanie dla ochrony klimatu. Spalanie węgla kamiennego i brunatnego w tej cywilizacyjnej transformacji się nie mieści.

Chyba nikt nie podważy stwierdzenia, że środowisko naturalne jest jednym z głównych czynników warunkujących zdrowie człowieka. Wszystkie dane, publikowane przez instytucje takie jak Światowa Organizacja Zdrowia czy naczelna Izba Kontroli wskazują, że głównym czynnikiem dewastacji środowiska człowieka - zwłaszcza poprzez zanieczyszczanie powietrza - jest wydobywanie i spalanie węgla kamiennego i brunatnego. Zatem, czy dla dobra wspólnego nie powinniśmy już teraz rozpocząć transformacji energetycznej w kierunku rozwoju obywatelskiej energetyki odnawialnej, nawet jeśli na razie bezpośredni koszt wytwarzania energii jest wyższy niż z paliw kopalnych?

Wszystkim pod rozwagę autor dedykuje dylemat: czy mamy żyć taniej lecz krócej, czy zdrowiej i dłużej.

\section{Bibliografia}

[1] Sanzillo T. (2015), The Case for Divesting Coal from the Norwegian Government Pension Fund Global, Institute for Energy Economics and Financial Analysis, Clevland

[2] Program dla sektora górnictwa wegla kamiennego w Polsce (2018), Ministerstwo Energii, Warszawa, https://www.teraz-srodowisko.pl/media/pdf/aktualnosci/4177-program-dla-sektora-gornictwa-kamiennego.pdf

[3] Ustawa prawo geologiczne i górnicze, Dz.U. z 2015 r. poz. 196

[4] Informacje o bilansie zasobów złóż kopalin, portal internetowy Państwowego Instytutu Geologicznego, zakładka Surowce mineralne, podstrona Surowce energetyczne $>$ Węgiel kamienny, http://geoportal.pgi.gov.pl/surowce/energetyczne/wegiel_ kamienny

[5] Rozporządzenie Ministra Środowiska z 1 lipca 2015 r. w sprawie dokumentacji geologicznej złoża kopaliny, z wyłączeniem złoża węglowodorów, Dz.U. z 2015 r. poz. 987, http://dziennikustaw.gov.pl/DU/2015/0987

[6] Nieć M. (2009), Polska i mięzynarodowa ramowa klasyfikacja zasobów (UNFC) złóż. kopalin stałych $i$ weglowodorów - podobieństwa i różnice, „Górnictwo odkrywkowe”, nr 
2-3, http://geoportal.pgi.gov.pl/css/powiaty/publikacje/gornictwo_odkrywko we/klasyfikacja_zasob.pdf

[7] Bilans perspektywicznych zasobów kopalin Polski - wg stanu na dzieñ 31 XII 2009 (2011), Państwowy Instytut Geologiczny - Państwowy Instytut Badawczy, Warszawa

[8] Bukowski M., Śniegocki A. (2014), Ukryty racbunek za wegiel - analiza wsparcia gospodarczego dla elektroenergetyki weglowej oraz, górnictwa w Polsce, Warszawski Instytut Studiów Ekonomicznych, Warszawa, http://www.greenpeace.org/poland/PageFiles/602721/Raport_GP_Ukryty_rachunek_za_wegiel.pdf

[9] Siedlecka U., Śniegocki A., Wetmańska Z. (2017), Ukryty racbunek za wegiel 2017. Wsparcie górnictwa i energetyki weglowej w Polsce - wczoraj, dzis i jutro, WiseEuropa, Warszawa, m.greenpeace.org/poland/PageFiles/762267/UkrytyRachunek2017_web.pdf

[10] Informacja o funkcjonowaniu górnictwa wegla kamiennego, portal Ministerstwa Gospodarki, od roku 2015 Ministerstwa Energii, http://www.me.gov.pl/Gornictwo/ Realizacja +Programu+dzialalnosci + gornictwa + wegla + kamiennego $+w+$ Polsce

[11] Quandl, https://www.quandl.com/data/BP/COAL_PRICES-Coal-Prices

[12] Energy security, International Energy Agency, https://www.iea.org/topics/energysecurity/

[13] Ustawa Prawo energetyczne, Dz.U. 2017, poz. 220

[14] Energia 2017 (2017), Główny Urząd Statystyczny, Warszawa, https://stat.gov.pl/files/gfx/portalinformacyjny/pl/defaultaktualnosci/5485/1/5/1/energia_2017.pdf

[15] Bukowski M., Maśnicki J., Śniegocki A., Trzeciakowski R. (2015), Polski wegiel: Quo vadis? Perspektyny rozwoju górnictwa wegla kamiennego w Polsce, Warszawski Instytut Studiów Ekonomicznych, Warszawa, http://wise-europa.eu/wp-content/uploads/2016/03/wegiel_raport_15_06_elektroniczny.pdf

[16] Funkcionowanie górnictwa wegla kamiennego w latach 2007-2015 na tle założeń programu rzqdowego (2017), Informacja o wynikach kontroli, LKA.410.038.2015, Nr ewid. 209/2016/P/15/074/LKA, Najwyższa Izba Kontroli, Delegstura w Katowicach, https://www.nik.gov.pl/kontrole/P/15/074/LKA/

[17] Rocznik Statystyczny Wojewódżtwa Ślaskiego 2016 (2016) Urząd Statystyczny w Katowicach, http://katowice.stat.gov.pl/download/gfx/katowice/pl/defaultaktual nosci/752/4/16/1/rocznik2016__.pdf 
[18] Rocznik Statystyczny Województwa Wielkopolskiego 2016 (2016) Urząd Statystyczny w Poznaniu, http://poznan.stat.gov.pl/download/gfx/poznan/pl/defaultaktualnosci /752/2/12/1/rocznik_woj_2016_pol.pdf

[19] Energy productivity, Eurostat, Code: sdg_07_30, http://ec.europa.eu/eurostat/ tgm/table.do? tab $=$ table\&plugin $=1$ \&language $=$ en\&pcode $=$ sdg_07_30

[20] Wilczyński M., (2013) Zmierzch wegla kamiennego w Polsce, Instytut na rzecz Ekorozwoju, Warszawa 